\title{
The teaching of bioethics in medical schools in Brazil
}

Waldemar Antônio das Neves Júnior ${ }^{1}$, Laís Záu Serpa de Araújo ${ }^{2}$, Sergio Rego ${ }^{3}$

\begin{abstract}
In Brazilian medical education and in the general teaching of bioethics in Brazil, there is a recurrent debate about the best way to teach ethics and/or bioethics, and even about whether it is possible to do so. In part this is due to the growing concern in society about the necessity of physicians to be both technically and morally competent. The teaching of bioethics is distinguished from medical ethics in that it focuses on the rights and duties of the doctor and also by its multi- and inter-disciplinary characteristics. The aim of the present study was to identify whether bioethics as a specific discipline is included in the curriculum of Brazilian undergraduate medical courses, and if so, how it is taught and what are its contents. The study found that the number of dedicated bioethics classes in medical courses has increased, and that the most frequently addressed issues are: an introduction to bioethics and principles of bioethics, the physician-patient relationship, abortion and euthanasia.
\end{abstract}

Keywords: Medical education. Bioethics. Higher education. Moral development.

\section{Resumo}

\section{Ensino de bioética nas faculdades de medicina no Brasil}

É recorrente, no âmbito da educação médica brasileira e no ensino da bioética de modo geral, o debate sobre a melhor maneira de ensinar ética e/ou bioética. Parte disso decorre da crescente preocupação na sociedade de contar com médicos técnica e moralmente competentes. $O$ ensino de bioética distingue-se do ensino de ética médica, já que esse último está centrado nos direitos e deveres do médico, enquanto o primeiro tem seu foco na multi, inter e transdisciplinaridade. O objetivo deste trabalho é identificar se a disciplina de bioética encontra-se na matriz curricular, como é ministrada e quais são os conteúdos trabalhados nos cursos de medicina do Brasil. Observou-se aumento do número de oferta de disciplinas autônomas de bioética nos cursos médicos e que os temas mais abordados pelas disciplinas são introdução à bioética e princípios da bioética, relação médico-paciente, aborto e eutanásia.

Palavras-chave: Educação médica. Bioética. Educação superior. Desenvolvimento moral.

\section{Resumen}

\section{La enseñanza de la bioética en las escuelas de medicina en Brasil}

Es muy común en el ámbito de la educación médica brasilera y en la enseñanza de la bioética en general, el debate sobre la mejor manera de enseñar la ética y/o la bioética. Parte de esto se debe a la preocupación cada vez mayor en la sociedad para que tengamos médicos técnica y moralmente competentes. La enseñanza de la bioética se distingue de la ética médica; ésta última está centrada en los derechos y deberes del médico, mientras que la bioética se caracteriza por ser multi, inter y transdisciplinaridad. El objetivo de este estudio es identificar si la disciplina Bioética está en los planes de estudios, cómo se la enseña y cuáles son los contenidos trabajados en las carreras de Medicina de Brasil. En la investigación se observó que hubo un aumento en el número de asignaturas de Bioética autónomas en las carreras de Medicina y que los temas más discutidos son: Introducción a la bioética y principios de la bioética, la relación médico-paciente, el aborto y la eutanasia. Palabras-clave: Educación Médica. Bioética. Educación Superior. Desarrollo Moral.

\section{Aprovação Ensp/Fiocruz 41664615.3.0000.5240}

1. Doutorando waldemarneves@hotmail.com - Universidade Federal de Alagoas (Ufal), Maceió/AL. 2. Doutora laiszau@uol.com.br Universidade de Ciências da Saúde de Alagoas (Uncisal), Maceió/AL, Brasil. 3. Doutor starego@gmail.com - Escola Nacional de Saúde Pública Sérgio Arouca (Fiocruz), Rio de Janeiro/RJ, Brasil.

\section{Correspondência}

Waldemar Antônio das Neves Júnior - Rua Raul Pompeia no 131, apt. 1005, Copacabana CEP 22080-001. Rio de Janeiro/RJ, Brasil. 
In the last decades much has been discussed about the transformations that have resulted from scientific, technological and social development, as well as their implications in the large areas of knowledge, especially in biological sciences, health care and public health. Recently, market demands have required new capacities and competencies from professionals so they can adapt to the new changes, whether technological, scientific, conceptual or in terms of values, especially in regard to ethical training.

In the center of these changes certain paradigmatic transitions have occurred, demanding a period of adaptation from the existing models which no longer correspond to social demands and the technical and professional framework. Such changes have become necessary to the extent that previous scientific paradigms have failed in the attempt to respond to problems which arise from the scientific advances that have been occurring since the late 18th century, also including medicine ${ }^{1}$.

Certain regulated and socially instituted professions, such as medicine, follow norms and rules regarding their exercise and this is the area in which medical ethics is located, given its normative character, when it refers to the set of rights and duties to be followed in the medical practice. What characterizes this discipline is the method, which consists in judging if a certain conduct is or is not in agreement with the ethical precepts adopted by the profession. These precepts are understood as duties from which professionals cannot "stray" if they want to be morally correct in their conduct.

Carneiro and collaborators ${ }^{2}$ state that for a long time this model was the basis for teaching ethics in health courses and, regardless of its importance, has proven insufficient. In spite of the reformuations carried out by the Câmara Técnica de Bioética do Conselho Federal de Medicina (Technical Bioethics Chamber of the Federal Council of Medicine - CFM) it is necessary to adequate the teaching of bioethics to these changes, and to the changes that have occurred in society. Currently it has become clear that, for the ethical training of medicine professionals, it is not enough to solely understand ethics based on deontological codes in which values and norms are imposed as heteronomous adaptation mechanisms which consolidate the authoritarian power of social norms.

Several ethical issues arise upon contesting the traditional paradigm of ethical training in medicine, so that there is a need for phylosophical reflection aimed at mediation and decision making in an attempt to solve these conflicts ${ }^{1}$. To morally educate someone it is necessary to prioritize examples when working with daily tasks that are known by students and teachers. Therefore, this is not a question of merely thinking about incorporating them to our professional activity, but also of evaluating how we execute them in order to improve the ethical sense of our actions and thus detect the aspects which we deem positive and negative ${ }^{3}$.

In the realm of Brazilian medical training in general, and in the teaching of bioethics, the debate over the best way to teach ethics and bioethics ${ }^{4}$, or even if it is possible to convey this knowledge to students, is recurrent. There is great concern and demand from a portion of society for the medical profession to have morally competent professionals; however, medicine students are still trained to deal only with the technical aspects of the profession, not with the ethical and moral ones ${ }^{5}$. Therefore, conflicts and dissactisfaction emerge from both parties, as well as the interest of universities to readapt the strategies of their political and pedagogical projects (PPPs) and their education philosophy in an attempt to adequate their curriculums to the new demands made by society, so that this reformulation is geared towards the inclusion of disciplines of ethical and philosophical nature in the basic training stages ${ }^{6}$.

Ethics is a part of philosophy, a type of knowledge that has constituted itself in a rational way and which relies on conceptual rigor, methods and explanations that are proper of philosophy ${ }^{7}$. Ethics is founded on three prerequisites: 1) consciousness or perception of conflict; 2) autonomy, an individual's capacity to position him or herself between emotion and reason by way of an active, autonomous choice; 3) coherence $^{8}$. It is known that people are not born ethical, but they have a priori conditions for ethical thinking and moral development to be built and introjected along time, and for this reason these must be stimulated.

Some authors such as Rego ${ }^{9}$ point out the importance of the discussion about moral education in order to break away from the model of imposition and indoctrination which is out of context, archaic and inneffective, and to a large extent the one upon which some teachers still base their teaching of the medical ethics discipline. There are teachers who consider that they have "taught" medical ethics to their students solely by transmitting the norms of the Código de Ética Médica (Medical Ethics Code - CEM), or the deontological "should do" in each situation.

Cortina ${ }^{10}$ states that when we talk about education, especially moral education, it is necessary 
to distinguish between indoctrinating and educating in order to understand what is desired out of moral education. According to the author, when one talks about indoctrinating one wishes to convey moral content to students, and by giving answers teachers avoid them to keep thinking and confine them to their own moral universe - which she calls "closed moral". From an educational perspective it is necessary to open new content to allow for students to think morally on their own and make decisons based on their autonomy - which Cortina classifies as "open moral".

For this reason, bioethics is inserted in a wider context because it arises from the demands of society which questions the very legal limits of the practice, connecting to the effective exercise of citizenship itself $^{11}$. In addition, bioethics is distinguished from the deontological view for having multi, inter and trans-disciplinary characteristics ${ }^{6}$.

The main characteristic, regarding the initial meaning of the word "bioethics" in the legacy of Van Rensselaer Potter in 1971, was to establish it as a philosophical discipline ${ }^{12}$. Still according to him, bioethics has advanced as a new discipline which combines biological knowledge and a system of human values. Potter, quoted by Reich ${ }^{13}$, thus explains the formation of the term "bioethics": I have chosen the prefix bio to represent biological knowledge, the science of living systems; and ethics to represent the system of human values ${ }^{13}$. Ever since, there has been growing interest on the philosophical foundation of bioethics based on ethics, which shows, on the one hand, the interest of the authors of the area on bioethics for the ethical cornerstones and, on the other hand, the interest awoken in philosophy especially due to ethical issues and the debate on bioethics ${ }^{14}$.

Kottow ${ }^{15}$ considers that bioethics undoubtedly behaves as a social phenomenon and also as a discipline, given its consistent academic presence in regular, departmentalized courses with specialized faculties on different areas. What was at first an ideal and an intuition by some physicians and scholars from several nations who planned on spreading the interest for this new discipline is now a reality ${ }^{14}$. Due to its concern with the correct use of new technologies in the area of medical sciences and with adequate solutions for the moral dilemmas presented by them, the field is considered as applied ethics. It would, therefore, be a specific branch of moral philosophy, with its own characteristics ${ }^{16}$. This way it is noticeable that bioethics has matured as a form of practical moral philosophy in medicine ${ }^{17}$.
Based on the results of their studies, Boylan and Donahue ${ }^{18}$ supply the structure for a practical scenario with concrete suggestions to introduce ethical issues in university curricula. The idea and the rethinking process of this structure will allow for university students and professors to approach a wide array of ethical issues which may arise in classroom discussions, both in academic disciplines and in professional training.

Some studies, such as the one by Lind ${ }^{5}$, have concluded that medical training does not contribute to the moral development of the students. Moral education converges towards the constructivist thinking with historical and social anthropological orientation, according to which the training of the human being is accomplished by means of social interaction, that is, through an individual's relationship with other individuals and through their actions on the world ${ }^{19}$. To Mizukami ${ }^{20}$, teaching is influenced by human development and knowledge is essentially active. The author states that one of the fundamental implications for an individual is that the intelligence is constructed from the exchanges between the organism and its environment and in its actions. This action, in our understanding, is the center of the training process and the social and educational factor which constitutes a condition for the development of the individual.

The main goal of the teaching of bioethics must be to develop in the students the process of finding solutions which involve several abilities, which Kohlberg, quoted by Lind", calls "capacity for moral judgment" and defines as the capacity to make decisions and making judgment that is moral, that is, based on internal principles and in acting according to such judgment. This presupposes the competence to identify and distinguish individual moral interests (autonomy) from collective moral interests (heteronomy), in addition to the permanent condition of being a socially unfinished individual ${ }^{6}$, in the form of a continuous exercise for the construction of one's moral personality.

Currently, the new Diretrizes Curriculares Nacionais (DCN - National Curricular Directives) for the undergraduate medicine courses ${ }^{21}$, put into effect by the Ministry of Education (MEC) on June 20,2014 , determine that graduating students must be trained to substantiate quality in health care and be guided by their critical thinking, and that professional ethics must be founded on the principles of ethics and bioethics. This is an attempt to guide the development of competencies during medical training, recommending in which way the future 
professionals should act in respect to their moral behavior $^{6}$.

The DCN point out the competencies and abilities expected to be developed by medicine students in their professional training process ${ }^{9}$. Its intent is to put forth several perspective proposals in response to a wide array of problems, ranging from the propagation of certain ethical, esthetic and political perspectives to the suggestion of procedures and competencies which must be part of the shared national curricula base 22 . It becomes evident that there is recurring debate on the best way to teach ethics and/or bioethics, or if it is possible to teach them in the realm of Brazilian medical education in general and in the teaching of bioethics ${ }^{4}$.

There is also the concrete issue of real or apparent lack of interest from the teaching institutions, according to Goergen ${ }^{19}$, on what may or must be done in terms of ethical education. For the author this derives from current times, in which there is an emergence of conflicts that are inherent of a plural, democratic society which still has not found either consensus around the values nor the disposition to instil in youngsters the values or forms of behavior that are not shared by all.

This discussion suggests a renewal of school practices and curricula due to the ethical conflicts, in the way how the content and the formative values to be taught may be clarified from the student's learning process in order to facilitate the educational process ${ }^{19}$. For this reason it is paramount that there is a commitment by the teaching institutions to the promotion of a conduct which is based on ethical principles of valuing a person's fundamental rights and obligations, which has ceased from being a subject restricted to specialists and education professionals and has become a matter of public interest ${ }^{23}$.

Upon reflecting on the ethical discourse of the competencies and abilities prescribed by the DCN one may ask: will the technicist trend incorporated in Brazilian education account for the training and moral education of future physicians? Will they be prepared for the mediation of the conflicts that will happen during their education and later professional activities? Do deontological disciplines such as medical ethics, deontology and forensic medicine bring education on values and moral development to these students?

For this reason the need has been considered to emphasize the relevance of moral education, or education on values (regarded here as synonyms) during professional training, since with its presence it is possible to optimize the creation of social multipliers, especially in the health area ${ }^{24}$. It would take seeing the university as a place of permanent exercise of ethics, of critical discussion of conflicts, of guidance for the future and of transmission not only of knowledge but also of judgments of value to the students. In Lind's ${ }^{5}$ perspective, moral and democratic competencies should not be acquired by indoctrination or old ways of "top-down" teaching, but rather be learned by children, adolescents and adults from "bottom to top", for example by means of the solution of "moral dilemmas" under the guidance of well-trained teachers.

Competencies are related to intelligence just as disciplines are to knowledge ${ }^{25}$. Therefore, specific knowledge organized in the form of disciplines must be rescaled in the perspective of making up an instrument in service of the development of intelligence with autonomy, and therefore, of personal development - a precondition for growth as a citizen and professional ${ }^{25}$. To Culver ${ }^{26}$, ethical training must be devised as a means of improving the character of future physicians and endowing the ones who already have it with skills and attitudes to allow them to have the best possible ethical performance.

In agreement with this perspective, Rego and collaborators ${ }^{11}$ state that the teaching of bioethics should have a double function: 1) contribute for students to develop/perfect their capacity for bioethical analysis and, therefore, for making decisions in situations which involve ethical issues; and 2) create citizens who are conscious and compromised with the common good. Correa ${ }^{14}$ states, in addition, that bioethics has started contributing for the reflection and public debate on themes related to fundamental values regarding life and science to be introduced in the school curricula of many undergraduate careers - among them health - and in the continuous graduate training of many professionals.

In face of what has been shown, this paper aims at 1) identifying how and where bioethics disciplines and themes are situated in the curriculum matrices of the medicine courses in Brazilian universities that have received scores 4 and 5 in the Exame Nacional de Desempenho de Estudantes (Enade - National Examination of Student Performance); verifying which bioethics topics are discussed in undergraduate medicine courses in Brazil; 3) identifying which of these themes have been used in the elaboration of Enade. 


\section{Materials and Method}

The data have been obtained by qualitative descriptive research, with data collection made available on the official websites of the Ministry of Education (MEC), of the Associação Brasileira de Educação Médica (Abem - Brazilian Association of Medical Education), of the medical schools in Brazil and the Instituições de Ensino Superior (IES - Higher Education Institutions) which have undergraduate medicine courses in Brazil with a score of 4 or 5 in Enade.

Included in the sample are all medicine schools (both public and private) which have taken part in Enade from 2010 to 2013 and have obtained scores 4 and 5 in these evaluations. The justification for this type of inclusion is that the conceito preliminar do curso (CPC - preliminary concept of courses) established by $\mathrm{MEC}^{27}$ combines eight components that indicate the quality of the course, out of which we list the six most relevant ones for the purposes of this paper:

- Infrastructure and physical facilities

- Didactic and pedagogical organization

- Characteristics of the faculty: number of professors with doctorate and masters degrees and full time or part time professors.

- Performance of graduating students

- Performance of Enade participants

- Indicator of the difference between the expected and observed performance (performance difference indicator - IDD)

All original measures pertaining to these components have been duly standardized and transformed into scores or grades between 0 and 5, with classification and criteria in accordance with MEC/ Enade. This way, the best teaching institutions in Brazil have been selected according to these criteria.

According to Frinkler ${ }^{28}$, the selection of these groups of universities with grading 4 and 5 at Enade is also due to other variables related to the teaching of medicine graduate courses, such as the scientific productivity and the introduction of new curriculum guidelines in 2014, including the school's performance and references in the national academic environment. Therefore, this can be considered as the first step, as a sample that reflects the resulting knowledge and experiences, seeking that the $\mathrm{HEl}$ courses can be adequately studied.

All universities with public data available on official websites of their respective HEI courses were considered. For this purpose, we analyzed all data related to the pedagogical course projects of the relevant courses (PCP), in the curriculum matrices and class planning program contents of these subjects. Issues on Enade ethics were also analyzed based on information obtained at the Instituto Nacional de Estudos e Pesquisa Educacionais Anísio Teixeira (Inep - Anísio Teixera National Institute of Educational Studies and Research) website, which is a federal autarchy linked to the MEC, seeking to find which of these topics were used in the evaluations, considering the years in which the Enade test was offered.

This research model, according to Bonet ${ }^{29}$, is important because the university is an environment in which academic aspects and everyday practice are interconnected, and at the same time, social, psychological and economic tensions are found. Medicine was selected as the object of study because it is the work environment of researchers; due to the researchers' concern with medicine students' ethical education; due to the fact that physicians frequently have to make decisions in delicate and potentially conflictive situations, including young professionals who are still getting used to "being" and becoming doctors and even because this affects all people living in society who need medical services, both to prevent disease and to regain a healthy condition.

The analysis technique was defined based on the guidelines set by Minayo and collaborators ${ }^{30}$, according to which in a real-life context and in a concrete case, it is necessary to try to learn about a phenomenon as a whole and describe it in a creative way, seeking to understand and interpret its complexity based on a number of evidences. Such evidence constitutes a database developed throughout research, therefore composing a chain of relevant evidence. It was also considered that unsurprisingly, discourse related to such concerns suggests a possible crisis of values typical of our society, as well as the need to renew our university practices and curriculum, prioritizing and emphasizing such goals, frequently considered as secondary or inexistent in past and present times, as Correia ${ }^{14}$ warns.

Consequently, this study seeks to identify if bioethics courses are being offered in medicine graduate courses in Brazil and how they are being taught in course curriculum matrices, considering the topics and teaching methodologies used. We believed that this report is of extreme relevance, once it responds to new ethical issues permanently incorporated to our reflection, bringing elements to work on the urgent need for teaching renovation and modernization. ${ }^{31}$. 


\section{Discussion of results}

According to the e-MEC portal, today there are 260 faculties of medicine registered in Brazil, out of which 177 took part in the triennial Enade 2010 and 166 participated in the last 2013 triennial, obtaining grading concepts that fluctuated from 1 to 5 . An important data is that currently, a specific evaluation type for medicine courses is under analysis. For this purpose, an open public consultation was prepared by INEP, seeking to create evaluation instruments in agreement with the new medicine courses guidelines ${ }^{32}$.

During the study carried out based on the e-MEC and official HEI websites, we verified that 93 medicine faculties achieved grading 4 and 5 at Enade in these triennials, from which $(81.7 \%)$ made some course data available and 17 (18.3\%) did not offer any information, matrices, curriculum summaries and/or program contents. After analyzing the 76 PCP found, we identified that 10 medicine universities had no bioethics courses and that in 66 of them they were being offered as an independent subject or with other specification in the curriculum matrix. Thirty-two universities made their matrices available on their websites but not their curriculums or program contents.

Applying these exclusion criteria, with the number of evaluated courses $-n=66-$ we considered those faculties that offered enough data to have their curricular matrices analyzed in the PPC. Data obtained from the different courses was classified in three groups: $47 \%$ were independent subjects with bioethics contents and name, $38 \%$ had bioethics content and were linked to other subjects and $15 \%$ had names other than bioethics and were also related to other subjects (Table 1).

Table 1. Distribution of modalities and names of bioethics courses

\begin{tabular}{|c|c|c|}
\hline Bioethics course modality & Course name & Quantity \\
\hline \multirow{8}{*}{$\begin{array}{l}\text { Independent courses with } \\
\text { bioethics content and } \\
\text { name. }\end{array}$} & Bioethics & 21 \\
\hline & Bioethics and citizenship & 2 \\
\hline & Ethics and bioethics basics & 1 \\
\hline & Bioethics and health & 1 \\
\hline & Introduction to medical bioethics & 1 \\
\hline & Applied bioethics & 1 \\
\hline & Introduction to bioethics - optional & 2 \\
\hline & Bioethics - optional & 2 \\
\hline \multirow{10}{*}{$\begin{array}{l}\text { Courses with bioethics } \\
\text { content and linked to } \\
\text { other courses }\end{array}$} & Legal medicine and bioethics & 3 \\
\hline & Legal medicine/ethics/bioethics & 4 \\
\hline & Ethics and bioethics & 6 \\
\hline & Basics of ethics and bioethics & 1 \\
\hline & Bioethics and medical ethics & 4 \\
\hline & Bioethics and legal medicine & 1 \\
\hline & Deontology and bioethics & 3 \\
\hline & Philosophy and bioethics & 1 \\
\hline & Bioethics and ethical medicine - optional & 1 \\
\hline & Medical ethics and bioethics in clinical practices - optional & 1 \\
\hline \multirow{6}{*}{$\begin{array}{l}\text { Courses with contents and } \\
\text { name other than bioethics }\end{array}$} & Medical ethics & 4 \\
\hline & Ethics and human relations & 2 \\
\hline & Global assistance to the diseased: humanistic approach & 1 \\
\hline & Personal development: historical, scientific and ethical evolution of medicine & 1 \\
\hline & Ethics and psychosocial relations III & 1 \\
\hline & Collective health I and II & 1 \\
\hline
\end{tabular}


This confirmed three course models found in health graduate programs mentioned by Rego and collaborators $\left.{ }^{11}: 1\right)$ schools that offer only the teaching of professional ethics; 2) schools that offer bioethics teaching within a model based on problems adopted by the faculty and; 3) schools that offer bioethics as a separate course.

Still, in the Table 1 discussion, we find classifications based on the names of courses and their availability. We verified a growing number of bioethics courses and contents in medicine curriculum matrices, although they are still associated to other normative courses, as demonstrated by some research studies ${ }^{31-33}$. This growth becomes evident when we compare $47 \%$ of independent courses with bioethics name and contents found in our research with the study carried out in 2001 and mentioned in the Dantas and Souza ${ }^{31}$ study, in which they affirm that related courses named "bioethics" or "medical ethics" appeared in $16.6 \%$ of cases. This fact clearly suggests the need to strengthen bioethics as a legitimate knowledge field necessary for graduate courses, as well as the importance of distinguishing its contents from those of deontological courses. We can therefore affirm that the absence of bioethics in the training of future doctors difficults inter, multi and trans-disciplinary activities and that there is also the perception that ethical contents are transversal to those of other technical courses.

The differentiation between bioethics teaching and other courses becomes necessary for its development and reinforcement as an academic course, once it is no longer possible to teach bioethics in graduate courses based on general basic contents, normally offered together with other courses; it is also necessary to bring bioethics closer to its identity, demanding from teachers the capacity to teach with a clinical, juridical and philosophic bioethics perspective, with a bioethics methodology and within a bioethical environment ${ }^{14}$. According to Gracia ${ }^{34}$, if we expect that the teaching-learning process can help in the improvement of moral character and attitudes by acquiring knowledge and through skills development, it is necessary to work in an entirely interactive and participative way.

The impasse in the search for a better course contents analysis resulted from the difficulty to obtain information, considering the following distribution: $51.5 \%$ of faculties had course contents and programs available online, while $48.5 \%$ did not have either of them. Out of the content analysis and topics approached in the 66 courses found, only 34 were available on-line. When these courses were analyzed on the HEI websites, it was discovered that only 25 summaries and 9 program contents were available to the public and that in some cases, they were still incorporated and linked to courses with a different methodological approach than the one adopted in bioethics teaching.

The contents more frequently found in analyzed courses are introduced in Table 2 below.

Table 2. Distribution of bioethics courses contents in studied faculties

\begin{tabular}{|c|c|}
\hline Contents & Frequency \\
\hline $\begin{array}{l}\text { Introduction to bioethics: bioethics } \\
\text { principles }\end{array}$ & 22 \\
\hline Physician-patient relationship & 16 \\
\hline Research (experimentation) in humans & 15 \\
\hline Abortion & 15 \\
\hline Euthanasia & 14 \\
\hline Transplants & 11 \\
\hline Medical deontology & 11 \\
\hline Ethics, morals and law & 11 \\
\hline Public health & 10 \\
\hline Research Ethics Committee & 10 \\
\hline Human reproduction & 9 \\
\hline Medical errors & 8 \\
\hline Confidentiality and privacy & 8 \\
\hline Genetics, human genome & 8 \\
\hline Death & 8 \\
\hline Human rights & 7 \\
\hline Terminal care - palliative medicine & 6 \\
\hline Clinical research and clinical bioethics & 5 \\
\hline Assisted suicide & 4 \\
\hline Bioethics and research in animals & 4 \\
\hline Bioethics in medical emergencies & 4 \\
\hline Bioethics and the pharmaceutical industry & 3 \\
\hline Bioethics and the environment & 3 \\
\hline Aids and stigmatizing diseases & 3 \\
\hline Bioethics and spirituality & 3 \\
\hline Blood transfusions and Jehovah witnesses & 3 \\
\hline Human cloning & 2 \\
\hline Stem cells therapy & 2 \\
\hline Informed consent & 2 \\
\hline Violence and health & 2 \\
\hline Drugs & 1 \\
\hline Vulnerability concepts & 1 \\
\hline Global bioethics & 1 \\
\hline Glue sniffing (inhalants) & 1 \\
\hline Mariri tea & 1 \\
\hline Border and everyday bioethics & 1 \\
\hline
\end{tabular}

Source: PPP data from official HEl websites in 2015. 
Therefore, we can verify what research already revealed ${ }^{31-33}$ : among the matters that appear most frequently and that are mentioned as the most important ones in bioethics teaching are the beginning and end of human life, bioethics principles and research with humans. It is necessary to consider that these topics should not be restricted to rigid course programs. As moral norms are built through time, the modernization of teaching methods and contents updates affect the traditional course model ${ }^{35}$.

Another important issue is that this situation also helps to prove the incompatibility of teaching ethics through the conventional methodology, which uses a passive knowledge transmission approach merely through expositive classes, dealing with reality in a standstill mode, distant from the dilemmas experienced by physicians in the exercise of their profession. To make this change feasible, it is necessary to develop wide group discussions and also apply other pedagogical techniques, seeking that the group work can be effective ${ }^{11}$. It is necessary to rethink contents and topics, as well as to promote further discussions on applied teaching methodologies and techniques that enable the learning process and help in the ethical training of future doctors.

Analyzing the distribution of course modules, we notice that out of the 31 independent bioethics courses, 23 are offered in the first modules of their graduate course: two in the 10 module, two in the $2^{\circ}$, nine in the $3^{\circ}$, eight in the $4^{\circ}$ and two in the 50 module. It is possible that bioethics classes at the beginning of a graduate course can stimulate students to perceive opportunities to deal with common interest issues such as generating discussions and approaching situations that concern them. Besides, this also intends to take advantage of the fact that most youngsters, when entering university, are interested in exercising the profession guided by a spirit of benevolence and solidarity and the desire to help people ${ }^{36}$. As for the nine normative courses, such as medical ethics, legal medicine and deontology, they are offered closer to the time in which students start their internships, due to their relation to clinical practices: four courses are offered in the 70 module, four in the 80 and one in the 10․

We analyzed the questions on ethics found in Enade tests for the 2004, 2007, 2010 and 2013 triennials. In 2004, we identified five questions on ethics in the test, out of which four of them were on ethics and morals definitions and the remaining one on cloning. In 2007 there were two questions: one on confidentiality and privacy and the other on terminal patients and palliative care. In 2010 there were four questions: two on ethics definitions, one on aids and bioethics and the last one on terminal patients. In 2013 there were a total of four questions: two on secrecy and confidentiality, one on consent and one on the Código de Ética Médica (Medical Ethics Code) (Table 3).

Table 3. Distribution of triennials and questions found at Enade

\begin{tabular}{|c|c|c|}
\hline Year & $\begin{array}{l}\text { Quantity of } \\
\text { questions }\end{array}$ & Topics \\
\hline 2004 & 5 & $\begin{array}{l}\text { - } 4 \text { definitions on ethics } \\
\text { and morals } \\
\text { - } 1 \text { on cloning }\end{array}$ \\
\hline 2007 & 2 & $\begin{array}{l}\text { - } 1 \text { on secrecy and confi- } \\
\text { dentiality } \\
\text { - } 1 \text { on terminal patients } \\
\text { and palliative care }\end{array}$ \\
\hline 2010 & 4 & $\begin{array}{l}\text { - } 2 \text { definitions on ethics } \\
\text { - } 1 \text { on Aids and bioethics } \\
\text { - } 1 \text { on terminal patients }\end{array}$ \\
\hline 2013 & 4 & $\begin{array}{l}\text { - } 2 \text { on secrecy and } \\
\text { confidentiality } \\
\text { - } 1 \text { on consent } \\
\text { - } 1 \text { on the Medical Ethics } \\
\text { Code }\end{array}$ \\
\hline
\end{tabular}

Source: Anísio Teixeira National Institute of Education, Research and Studies. August 26, 2015.

Enade itself qualifies questions related to ethics and morals definitions as general knowledge questions, and the rest, as specific knowledge, all of them requiring objective answers. A relevant data is that general knowledge questions have a $25 \%$ weight and specific knowledge ones, $75 \%$ of the total test points. It is therefore clear that ethics does not hold much value in medicine programs, contrary to what NCG suggests and Enade advocates. The alleged concern about ethics education in professionals should be reflected in the evaluation criteria, as well as in the ethical care and the use of adopted teaching strategies and methodologies related to transversely and transversal issues linked to contents covered on many or even all course modules ${ }^{4}$.

It is understood that the Enade questions deserve a wider critique on the goals and purposes on which they are based. Besides, it would be necessary to stimulate critical thinking and understanding, bringing a critical reflection on ethics and bioethics closer to students' practices. This is, however, the issue that deserves the deepest discussion, as we believe it does not match the scope of this article. 
It is evident that one of the main current bioethics challenges is precisely its reaffirmation as a field of knowledge and as an academic course. Meanwhile, it is worth highlighting that the concern with the academic consolidation and dissemination of bioethics should not be restricted to specialization courses, medical residency, masters and doctorate programs. It should rather focus on reaching the graduation phase, where it could, without a doubt, contribute in a more effective way to the moral education of medicine students.

\section{Final considerations}

Although not all Brazilian medicine faculties were analyzed, due to the lack of HEI online data availability and updates, the information found allowed us to compare findings with those of previous research, corroborating that there was not just an increase in bioethics courses offered independently, but also in their inclusion and contents transfer to other associated courses, even assuming that their methodological approaches are different. Likewise, we verified that these bioethics contents and discussions are still related to normative courses contents such as medical ethics and deontology.

We also verified that there are a reduced number of independent bioethics courses, however with a moderate growth in the last few decades, which is also the case of specific courses with such name available in graduate courses. We identified that most curriculum matrices are aimed at the technical aspects of the profession, not giving the necessary importance to the ethical education of future physicians, which suggest the need for medicine faculties to adapt to the recent NCG for the 2014 medicine courses. In addition to this, we should also consider that most independent courses are offered during the first graduate modules. Among the most frequently approached matters we can mention bioethical principles, doctor-patient relationship, beginning and end of life and research in humans. Finally, this study concluded that there is a need to deepen and reassessing discussions on the goals and purposes of Enade's bioethical questions, so that they can fairly stimulate and ally ethical and technical education to make them part of the students' practice in medicine graduate courses.

Acknowledgements: Roberta Nascimento de Oliveira Lemos dos Santos, for her help in updating data for this research study.

\section{Referências}

1. Almeida JLT, Schramm FR. Paradigm shift, metamorphosis of medical ethics, and the rise of bioethics. Cad Saúde Pública. [Internet]. 1999 [acesso 9 maio 2013];5(Supl. 1):15-25. Disponível: http://www.scielo.br/pdf/csp/v15s1/0333.pdf

2. Carneiro LA, Porto CC, Duarte SBR, Chaveiro N, Barbosa MA. O ensino da ética nos cursos de graduação da área de saúde. Rev Bras Educ Med. [Internet]. 2010 [acesso 11 jun 2012];34(3):41221. Disponível: http://www.scielo.br/pdf/rbem/v34n3/11.pdf

3. Puig JM, García MX. As sete competências básicas para se educar em valores. São Paulo: Summus; 2010.

4. Silva RP, Ribeiro VMB. Inovação curricular nos cursos de graduação em medicina: o ensino da bioética como uma possibilidade. Rev Bras Educ Med. [Internet]. 2009 [acesso 13 mar 2012];33(1):134-43. Disponível: http://www.scielo.br/pdf/rbem/v33n1/17.pdf

5. Lind G. Moral regression in medical students and their learning environment. Rev Bras Educ Med. out-dez 2002;24(3):24-33.

6. Figueiredo AM, Garrafa V, Portillo JAC. Ensino da bioética na área das ciências da saúde no Brasil: estudo de revisão sistemática. Interthesis. [Internet]. 2008 [acesso 9 mar 2016];5(2):47-72. Disponível: http://bit.ly/1TLkp9D

7. Cortina A, Martínez E. O âmbito da filosofia prática. In: 2012. p. 7-26.

8. Cohen C, Segre M. Definição de valores, moral, eticidade e ética. In: Segre M, Cohen C, organizadores. Bioética. 3a ed. São Paulo: Edusp; 2002. p. 17-26.

9. Rego S. Diretrizes curriculares para os cursos médicos: e a educação moral? Caderno de Currículo e Ensino. 2001;2(4):25-32.

10. Cortina A. Educar na cidadania: aprender a construir o mundo juntos. In: mundo: para uma teoria da cidadania. São Paulo: Loyola; 2005. p. 171-95. Cidadãos do

11. Rego S, Palácios M, Schramm FR. O ensino da bioética nos cursos de graduação em saúde. In: Marins JJN, Rego S, Lampert JB, Araújo JGC, organizadores. Educação médica em transformação: instrumentos para a construção de novas realidades. São Paulo: Hucitec; 2004. p. 165-86, p. 170. 
12. Potter VR. Bioetica puente, bioética global y bioética profunda. Cuad Programa Reg Bioét. 1998; 7:22-35.

13. Reich WT. The word "bioethics": its birth and the legacies of those who shaped it. Kennedy Inst Ethics J. [Internet]. 1994 [acesso 4 abr 2010];4(4):319-33, p. 23. Disponível: http://www.ncbi.nlm.nih.gov/pubmed/10184226

14. Correa FJL. Trasmitir conocimientos, actitudes y valores al enseñar bioética. In: Correa FJL, editor. Docencia de la bioética en Latinoamérica: experiencias y valores compartidos. [Internet]. Santiago de Chile: Felaibe; 2011 [acesso 4 abr 2013]. Disponível: http://bit.ly/1QSg0ON

15. Kottow M. Antropología médica como propedeutica de la bioética: una propuesta curricular. Rev Bras Educ Med. [Internet]. 2005 [acesso 5 mar 2012];29(1):41-7. Disponível: http://www.educacaomedica.org.br/UserFiles/File/2005/antropologia.pdf

16. Clotet J. Bioética: uma aproximação. Porto Alegre: Edipucrs; 2003.

17. Jonsen AR. The birth of bioethics. Hastings Center Report. 1993;23(6):S1-S15.

18. Boylan M, Donahue J. Ethics across the curriculum. Lanham: Lexington Books; 2003.

19. Goergen P. Educação e valores no mundo contemporâneo. Educ Soc. [Internet]. 2005 [acesso 16 jan 2012];26(92):983-1011. Disponível: www.scielo.br/pdf/es/v26n92/v26n92a13.pdf

20. Mizukami MGN. Ensino: as abordagens do processo. São Paulo: EPU; 1986.

21. Brasil. Ministério da Educação, Conselho Nacional de Educação, Câmara de Educação Superior. Resolução CNE/CES no 3, de 20 de junho de 2014. Institui Diretrizes Curriculares Nacionais do Curso de Graduação em Medicina e dá outras providências. [Internet]. 2014 [acesso 9 mar 2016]. Disponível: http://portal.mec.gov.br/cne/arquivos/pdf/CES03.pdf

22. Carvalho JS. O discurso pedagógico das diretrizes curriculares nacionais: competência crítica e interdisciplinaridade. Cadernos de Pesquisa. 2001;112:155-65.

23. Carvalho JS. Podem a ética e a cidadania ser ensinadas? Pró-Posições (Universidade Estadual de Campinas). [Internet]. 2002 [acesso 12 fev 2012];13:157-68, p. 156. Disponível: http://bit.ly/1MiChRx

24. Sapiro CM. Teorias em desenvolvimento sociomoral: Piaget, Kohlberg e Turiel-possíveis implicações para a educação moral na educação médica. Rev Bras Educ Med. 2000 out-dez;24(3):7-15.

25. Machado NJ. Eixos teóricos que estruturam o Enem. Conceitos principais: interdisciplinaridade e contextualização. Brasília: MEC/Inep; 1999.

26. Culver CM, Clouser KD, Gert B, Brody H, Fletcher J, Jonsen A et al. Basic curricular goals in medical ethics. N Engl J Med. 1985;312(4):253-6.

27. Brasil. Ministério da Educação. Instituto Nacional de Estudos e Pesquisas Educacionais Anísio Teixeira. Cálculo do conceito preliminar de curso (CPC). [s.d.] [acesso 9 jun 2012]. Disponível: http://download.inep.gov.br/download/enade/2008/Nota_Tecnica_CPC_17_12_2009.pdf

28. Finkler M. Formação ética em odontologia: realidades e desafios [tese]. Florianópolis: Universidade Federal de Santa Catarina; 2009 [acesso 3 nov 2011].

Disponível: http://www.prosaude.org/noticias/finkler/teseMirelleFinkler.pdf

29. Bonet O. Saber e sentir: uma etnografia da aprendizagem da biomedicina. Rio de Janeiro: Editora Fiocruz; 2004.

30. Minayo MCS, Souza ER, Constatino P. Métodos, técnicas e relações em triangulação. In: Minayo MCS, Assis SG, Souza ER, organizadores. Avaliação por triangulação de métodos. Rio de Janeiro: Fiocruz; 2005.

31. Dantas F, Souza EG. Ensino da deontologia, ética médica e bioética nas escolas médicas brasileiras: uma revisão sistemática. Rev Bras Educ Med. [Internet]. 2008 [acesso 8 mar 2010];32(4): 507-17. Disponível: http://www.scielo.br/pdf/rbem/v32n4/v32n4a14.pdf

32. Brasil. Ministério da Educação, Instituto Nacional de Estudos e Pesquisas Educacionais Anísio Teixeira. Adequação dos indicadores dos instrumentos de avaliação presencial e a distância dos cursos de graduação em medicina. 2015 [acesso 26 ago 2015]. Disponível: http://bit.ly/1U1wWXd

33. Meira RA, Cunha MMS. O ensino da ética médica, em nível de graduação nas faculdades de medicina do Brasil. Rev Bras Educ Med. 1994;18(1):7-10.

34. Gracia D. Fundamentación y enseñanza de la bioética vol. 1. Ética y vida: estudios de bioética. Santafé de Bogotá: El Búho; 2000.

35. Rego S. Reflexão sobre o processo de formação ética dos médicos. Cadernos da Abem. 2004;1:28-9.

36. Rego S. O ensino da ética. In:___. A formação ética dos médicos: saindo da adolescência com a vida (dos outros) nas mãos. Rio de Janeiro: Fiocruz; 2003. p. 103-21.

\section{Participação dos autores}

Waldemar Antônio das Neves Júnior é responsável pela concepção do estudo, coleta de dados, desenho, elaboração e revisão do artigo. Laís Záu Serpa de Araújo e Sergio Rego participaram da orientação, elaboração e revisão do artigo.

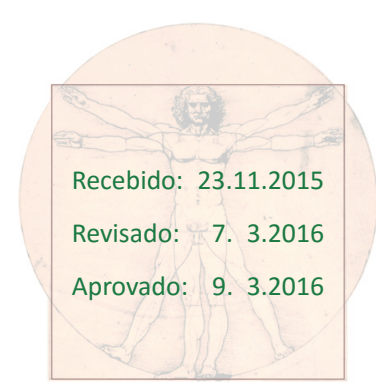

